\title{
The Research on Body Language's Role in English Teaching
}

\section{Mingxia Liu}

Shandong University of Technology, Zibo City, Shandong Province, China

\begin{abstract}
Body language plays a very important role in English teaching. Teacher's high spiritual status, humorous speech, vivid expressions, and visual gestures are all impressive. It can strengthen the effect of verbal education, build up a good and harmonious relationship between teachers and students. So the students are able to acquire knowledge in an easy and pleasant atmosphere; What's more, it can keep the classroom in order and enhance teaching efficiency. The younger learners need more cooperation of nonverbal signals because a monotonous and tense environment is likely to inhibit their intellectual performance. And the teacher's lively performance can shorten the psychological distance between teachers and students. In addition, it can enable students to better comprehend their materials and reinforce their attention to teachers.
\end{abstract}

Keywords_body language; English teaching; nonverbal communication.

\section{INTRODUCTION}

With the continual reform of language teaching and learning methods, English teachers are required to organize the class in English and create English-learning climate. However, because of the limitation of students' vocabulary in primary and middle schools, English teachers in primary and middle schools should not only use the oral language and written language to deliver the information, but also make use of the silent Body Language to simplify their teaching.

\subsection{The definition of body language}

What is body language? Body language is an important medium through which people can communicate with each other. It refers to the patterns of facial expressions and gestures that people use to express their feelings in communication. In school education, body language plays a positive role in cultivating the students' characters. For teachers are usually imitated by the students. In a word, teachers' graceful and lively body language help to improve students' artistic appreciation and moral character.

The body language transmits the information through the body movement or the posture. It is one kind of subconscious non-language act and it is also a method of expressing thought and emotion. Non-verbal communication not only includes tendency, but also includes static state. The former is the hand signal, the facial expression and the any spot of body's movement, for example: Nips the lip, indicates the worry impatiently; People smile when they are happy but pull the long face when they are unhappy or angry; red face means shy and wrinkling the brow means worry or pondered. The latter includes the addition of the body gives the person the certain information, for example: With what kind of handkerchief, the perfume, the lipstick, pull out what kind of smoke, wearing a hat or not and so on. All these information have the very tremendous influence on the human relations. We may use body language independently, also may coordinate with the language, following language and other body languages. Using the body language when speaking will make the listener obtain the concrete image and to be easy to understand, also will cause the listener to have the interest but not feel boring, and increase the stereoscopic effect for the words.

\subsection{Total Physical Response}

Total Physical Response is a language teaching theory which attempts to teach language through physical activities. It emphasizes comprehension and the use of physical actions to teach a foreign language at an introductory level. In teaching a foreign language, James 
Asher (James Asher, 1982), the advocate of the theory, believes that the Total Physical Response sees successful adult second language learning as a process paralleled to child first language acquisition. He feels that adults should follow the processes by which children acquire their mother tongue in learning a second language. Asher also shares with the school teachers when they are teaching foreign language and they'd better use the Total Physical Response teaching mind to facilitate students' learning. He believes that if a method does not require the foreign language learners to produce language until they are ready and if it involves body movements. The general objective of the Total Physical Response applies to students, especially at a beginning level. Teachers are typically used to elicit physical actions and activity on the part of the learners. Body language is a main teaching method of Total Physical Response, it can help students in primary and middle schools learn English much easier.

\subsection{Students' characteristics}

Using body language in English teaching in primary and middle schools can arouse students' interest in English learning, due to the students' characteristics. Firstly, attention of students of primary and middle schools is unstable and impersistent. Moreover, it is rather related to their interest. Only when the matter is vivid, particular and novel, will students pay much attention to it. Conversely, they will be absent-minded. Secondly, as the main form, the concrete thinking in image increasingly changes into the abstract thinking in logic which is the fundamental characteristic of students mental development. However, the abstract thinking in logic is closely linked to perceptual experience. For example, as for "big" and "small", the two words are distinguished by students' direct sense for real objects. Thirdly, students in primary and middle schools are not good at making sense of their emotion, mainly tied with their study life. Lastly, students' memory is unconscious, special and inflexible. As time goes, their abstract me mory generally takes shape. Therefore, English teachers in primary and middle schools should use body language to improve students' interest in studying.

\section{THE IMPORTANCE OF BODY LANGUAGE}

Studies have revealed some fascinating facts about our use of body language. For example, estimates show that the average person speaks for only ten to eleven minutes per day and that the average spoken sentence spans about 2.5 seconds. Body language is a significant area of communication study for at last three reasons, which are explained by Garner (1989). First, body language accounts for much of the meaning we derive from conversations. One level of meaning is the actual state message. We label this the cognitive content-what is said openly. It is the part we consciously process. We also have feeling about another person and the conversation that we just had. This feeling is called the affective content, which is the conveyance of feeling. Secondly, body language spontaneously reflects the subconscious. We normally attempt to control over the words we say. Occasionally we may slip up, lose control over our words, and have to apologize, but usually some degree of control is there. However, we may leak our true feelings in other, subtler behaviors. In fact, even accomplished liars can be detected by subtle nonverbal cues they unknowingly emit. Thirdly, body language is so significant that we cannot communicate even if we choose silence, and the nonverbal dimension of our communication is always present. Even if we remove ourselves bodily from the scene of interaction, our absence may speak loudly.

\subsection{The importance of using body language in English teaching}

The use of body language is a useful method in English teaching. In the classes, the students' attention can be attracted and the teaching quality can be improved if teachers use it properly. The use of gestures and facial expressions of teachers in the teaching process is important. They will help teachers express their own ideas and thoughts accurately and lively. According to the students, the use of body language will help them keep firmly in mind the knowledge obtained in class. Body language contains facial expressions, eyesight, movements and so on. They have some concrete functions in school teaching.

\subsection{Facial expressions}

In the teaching process, teachers provide the students with messages or issue orders through their own facial expressions. In the process of classes' exchange, teachers express their affection, optimis $m$ and deep confidence to the students. The students will feel warm and become 
active. The facial expressions of teachers in English teaching should change along with the changing of class contents and teaching circumstances. Also teachers' delight, anger, sorrow and joy should appear at the right moment, infect the students to have the feelings of delight and sorrow at the same time. They can't take their own passive morals into the classroom. As soon as they stand on the platform, they should smile and have their faces covered with youthful spirit even if they are in the worst mood .Strict and dull faces are not welcomed.

\subsection{Eyesight}

Eyes are windows of heart. The high administrative levels of education are the exchange and harmony of heart. Through the window, teachers transmit information which can't be expressed by verbal language to the students. An excellent teacher should have a pair of eyes which can speak.He / She should be good at using eyes to transmit messages, exchange feelings, express attitudes and carry on teaching. If the teacher stared angrily at the students who did not concentrate his attention nor did some petty actions in classes, the students would restrain himself consciously. When a student didn't answer a question for a long time because of his shame of making mistakes, an encouraging of eyesight from his teacher would make him become more confident than before.

\subsection{Movements}

The main movement is gestures. Gestures are the most important part of body language. The English teaching in classes focuses on communication activities. Dull and dry communication will make students produce detestable feelings, but lively, vivid, even exaggerated actions and gestures can enliven the teaching circumstances, making the activities go of without a hitch. If the teacher gives a ball's shape through his hands, then performs the action of shooting a basket when teaching the word 'basketball', all of the students can guess the meaning of it. Similarly, if the teacher imitates the usual gestures of monkeys, winks at the students mischievously and then leaps and jumps for a while when teaching the word 'monkey', these movements will affect the students intensely and attract their interest and get the function of intensifying their memory. When the teacher teaches a verb, it will be more accurate to do a simple gesture to the students than teachers' repeated explanation. And the students can remember it with a deep impression. Patting up one's thumb expresses 'OK' and 'GREAT'. And nodding shows yes and shaking one's hand shows no. These are all in common use.

We can also realize some foreign teachers are adept in using their own gestures and facial expressions to help their verbal language. The result is that the classroom teaching becomes vivid and interesting. Thus students learn a lot and remember many short and useful sentences such as 'I have a stomachache', 'I am spiting', 'I have a bad cold', 'I have a high fever', 'I have a headache'. These are all very common in English learning.

From all the above, we find that body language plays a positive role in the English teaching. Body language has strong characteristics in images and informative functions. It can make the abstract things become specific. In brief, English subjects are not like other subjects. English subjects have not a language atmosphere, so teachers' own creativity becomes necessary. In order to practice and improve the students' ability to think in English, teachers should do their best to reduce their use of Chinese in classes. Then body language will become the main medium through which teachers and students communicate with each other. The in fluences of teachers' body language on the students are reflected not only establishing a good example, but also shortening the teacher-student estrangement by which a more harmonious studying atmosphere is created. In the English teaching, body language needs to be used frequently so as to improve the teaching effect and the students' ability.

\section{THE CONCRETE APPLICATION OF BODY}

\section{LANGUAGE}

\subsection{Body language helps to improve listening}

To understand others is a basic purpose in English teaching, and teachers often train the students' listening accordingly. In this process, if the body language is used, the effect will be better. When beginning a new lesson, the teacher narrates the story outline in English. The body language may help. For example, a teacher can stretch his arms slowly when he says "She is in a very big room"; he can open his eyes widely with mouth opened when he says "She is so beautiful a lady". As a result, the students will have such an impression: She is very beautiful indeed; a 
teacher who imitates the crying or the movement of the animals under the premise of teaching order will surely achieve a better effect.

\subsection{Body language helps to improve speaking}

The spoken language is one of the important ways to communicate, so we should try to develop the students' ability to speak. Factually they are helped to reach the aim in a certain degree by their teacher's body language.

The contemporary emphasis is gradually laid on spoken English teaching. The first lesson of every unit in Senior English begins with dialogue. The teaching programs require the teachers to organize the class to practice English according to the characteristics of dialogue. Generally speaking, the body language can arouse and sustain the students' interest of learning and using English. In the English class, the teachers should not only use body languages themselves, but also ask the students to use them according to the different situation. Take it for example, the first lesson in Unit one, Book one is about the time when the new students first meet, and they don't know each other. So a teacher can introduce himself first, such as: "Hello, everyone, nice to meet you here. Now I'll introduce myself to you. My name is Arthur. I like playing basketball, for, it makes me much stronger; I like playing chess, for, it makes me more clever; and I like reading books, for, 'reading makes one perfect'". During the introduction, the teacher should use the new vocabularies and sentence structures together with a vivid expression and mating gestures as possibly as he can. He smiles when he says hello to the class; he shakes hands with some students saying "Nice to meet you"; he writes name down on the blackboard; he imitates the action of dribbling and shooting at the basketball, playing chess and turning pages to exp lain his hobby. After his introduction, the teacher can create a circumstance for the students to practice: "Mary and Jack are new classmates. They are walking together in the street, and they meet one of Jack's old friends, Yangpei. Then Yangpei and Mary are introduced to each other by Jack." After the students' practice the dialogue is introduced naturally from it. Usually, the application of body language in different situations will result in an attracting and successfullesson.

\subsection{Body language helps to improve reading}

In the senior school, we lay emphasis one the reading ability that serves the students' further study. Here we mainly mention the helpfulness for reading aloud. Reading aloud helps the students to get a correct pronunciation and intonation and to develop the combination of the vocabularies' pronunciation, spelling and meaning. Furthermore it also helps the students to find out the article's internal feelings and appreciate the beauty of the language. A linguist ever said: "A poem is not a poem until it is read." Reading aloud is basic in the middle school, and the teachers should make full use of body language to develop the students' ability of reading aloud.

When reading the sentences, attention should be paid to where to speak softly, emphasize, and raise or lower our tone. To make it clear, we can imitate the strong or soft pats that are used in music teaching, which means to use the arcs to represent different tones. Generally speaking, we use falling tones in declarative and special interrogative sentence, first rising tones and then falling tones in the choosing interrogative sentence. The students in the middle school are not often accustomed to and always confuse them; however, with the help of body language, they can solve the problem much more easily. For example, they use gestures. As they read the choosing interrogative sentence, they raise their hands in rising tones and lower in falling tones. After training for some times, as soon as they read the sentences, they will remind themselves of the gestures. As a result, there will be no problems in rightly reading the sentences at all.

In a word, the vivid gesture together with the fluent English can create a good circumstance of learning, which will surely play an active part in improving the students' reading ability.

\subsection{Body language helps to improve writing.}

Writing is one of the four basic skills of learning language, and it is so important skill that we can even say without it. To get rid of the students' feelings of being dull and tiring, an English teacher has to use every possible method. This is the same to the writing. Teachers use different methods in order to improve the students' ability to write, among which, the application of body language can deepen the object impression; such is magnificent in developing the students'writing ability.

The linguist Franklin ever said, "Tell me, I'll forget; teach me, I'll remember; involve me and I'll learn." If we 
asked the students to write an unfamiliar composition, they would probably be unable to and feel discouraged. However, the students can write excellent articles if they have the experience. In and out of class, we should ask the students to participate in some English-related activities, and then ask them to write it down. Take "The First Snow in winter" for example, having enjoyed themselves in the beautiful snowing and been given some hints, the students can write much better a composition. For contrast to their complete imagination, the students are deeply impressed by the body movement of the teachers and themselves, which surely leads to a better article.

\section{TIPS FOR USING BODY LANGUAGE IN ENGLISH TEACHING}

Using body language helps to arouse the students' interest and helps them to learn better. So body language is very important. However, Eng lish teachers seldom realize that they should use proper body language in their teaching. There are some advices for using body language in English teaching.

Firstly, do not use body language excessively. The 45 minutes in class is very precious and body language is a kind of auxiliary teaching means. If teachers use too much body language, they may take up too much time and cannot finish the planned task. To make it worse, too much body language will distract students' attention from the class. In the whole class, students will only focus on the teacher's body language and not pay much attention to the knowledge.

Secondly, students in primary and middle schools are apt to imitate the teachers' behavior. If the teachers act vulgarly, it will have a bad influence on the primary and middle school students. So teachers should be graceful and elegant. Good body language can reflect the teachers' temperament and demeanor to strengthen their personal glamour.

Thirdly is the gender problem. If a male teacher treats a girl, his body language must be properly. Otherwise, his intention will be misunderstood. All in all, teachers should use body language properly and show the positive aspect of body language.

\section{CONCLUSION}

When people interact, they rarely trust in words alone.
Nonverbal behaviors convey powerful messages because they are highly believable and they indicate the relationship between communicators. Therefore, nonverbal communication plays a significant role in our daily life and it cannot be ignored because nonverbal commun ication has a credible and powerful influence on our daily classroom teaching and learning.

However, it is hoped that this paper helps to enhance awareness of the fact that nonverbal communicative competence itself is a requirement in English teaching. Not only should English teachers be equipped with knowledge of nonverbal communication, but also the students should be encouraged to improve their nonverbal communicative competence.

\section{REFERENCES}

[1] Abeles, H.F. Student perceptions of characteristics of effective applied music instruction: Journal of Research in Music Education, 1975, 23.

[2] Birdwhistell, B. The Kinesis in Context. University of Pennsylvania Press, 1970.

[3] Ekman, P\& Friesen, W. Emotion in the Human Guidelines for Research an of Findings. New York: Pergamon, 1971.

[4] Jamati, P. Body Language in Teaching. Blackwell Publishers ltd, 1986.

[5] Jeremy, Harmer, How to Teach English, Beijing: Foreign Language Teaching and Research Press, 2000.

[6] Lusting. M. W. The Use of Body Language, 1995.

[7] Lyons, John. Body Language. The MIT Press, 1989.

[8] Richmond, V. \& McCroskey, J. Nonverbal behavior in interpersonal relation (3rd ed.) 1995. 